\title{
Effect of Scopoletin on Apoptosis and Cell Cycle Arrest in Human Prostate Cancer Cells In vitro
}

\author{
Chun-Long Liं, Xian-Cheng Han, Hong Zhang, Jin-Sheng Wu and Bao Li \\ Department of Urology, Affiliated Hospital of Weifang Medical University, Weifang 261031, China
}

*For correspondence: Email: chunlongli274@gmail.com; Tel/Fax: 0086-536-8068850

Received: 5 November 2014

Revised accepted: 14 March 2015

\begin{abstract}
Purpose: To investigate the anticancer activity of scopoletin against human prostate cancer. Methods: The anticancer activity of scopoletin was evaluated by 3-(4, 5-dimethylthiazol-2-yl)-2, 5diphenyltetrazolium bromide (MMT) assay. Flow cytometry using propidium iodide and annexin V-FITC was employed to study apoptosis and cell cycle analysis. Hoechst 33258 staining was used to assess the effect of scopoletin on cell morphology and apoptotic body formation in human prostate carcinoma ( $L N C a P)$ cells via Florescence microscopy and finally Western blotting was used to evaluate the effect of scopoletin on cyclin D1 and cyclin B1 expressions.

Results: Scopoletin induced a dose-dependent growth inhibition in LNCaP prostate cancer cells. It induced G2/M phase growth arrest and led to an increase in the sub-G0/G1 cell population after treatment with increasing doses compared to control cells, scopoletin treatment resulted in cell shrinkage along with membrane blebbing which are characteristic features of cell apoptosis. Approximately 15.45, 32.6 and $21.71 \%$ of the cells underwent early apoptosis after treatment with 40 , 80 and $100 \mu \mathrm{M}$ of scopoletin respectively. Cyclin D expression diminished in a concentration-dependent manner when LNCaP cells were treated with different concentrations of scopoletin.

Conclusion: These results reveal that scopoletin may be used as a natural chemotherapeutic agent against prostate cancer.
\end{abstract}

Keywords: Prostate cancer, Apoptosis, Cell cycle analysis, Scopoletin, Flow cytometry, Fluorescence microscopy

Tropical Journal of Pharmaceutical Research is indexed by Science Citation Index (SciSearch), Scopus, International Pharmaceutical Abstract, Chemical Abstracts, Embase, Index Copernicus, EBSCO, African Index Medicus, JournalSeek, Journal Citation Reports/Science Edition, Directory of Open Access Journals (DOAJ), African Journal Online, Bioline International, Open-J-Gate and Pharmacy Abstracts

\section{INTRODUCTION}

Prostate cancer is the most frequently diagnosed malignancy in males and the second leading cause of cancer-related death in men after lung cancer in United States of America [1]. Despite a similar prevalence of latent prostate tumors around the globe, incidence rates for clinical prostate cancer in Western men are 30-50 times higher than those for Asian men and the reason for this difference is unclear. In the United States, prostate cancer accounts for $32 \%$ of all cancer cases in men whereas in Shanghai (China), prostate cancer accounts for less than $1 \%$ of all cancers in men.

However, recent data suggest that prostate cancer rates are increasing [1]. In spite of substantial progress in prostate cancer treatment, the survival rate for advanced stages of this particular cancer has not considerably improved during the past decade [2,3]. Furthermore, standard treatment preferences for localized prostate cancer (surgical, radiation, and hormonal therapy) are accompanied with complications that often deteriorate patients' 
quality of life, such as urinary incontinence and sexual dysfunction. Therefore, prostate cancer patients seek complementary and alternative medicine (CAM) treatments in the hope of suppressing or slowing down disease progression to improve the general quality of life. Recent surveys demonstrated that approximately $40 \%$ of prostate cancer patients utilize various CAM modalities as a component of therapy [4-6].

Scopoletin (6-methoxy-7-hydroxycomarin) is a phenolic coumarin and an important member of the group of phytoalexins isolated from many plants, and also a prominent coumarin derivative occurring in various plants [7-10]. It has also been reported to be an active component in the plants such as Erycibe obtusifolia, Aster tataricus and Foeniculum vulgare. These plants have been used in traditional Chinese medicines for the treatment of various diseases with a long history. A variety of biological activities like antiinflammatory, anti- allergy and anti-angiogenesis have been reported for scopoletin [11-14]. The aim of the current research work was to evaluate the anticancer activity of scopoletin against prostate cancer cells in vitro by studying its effect on apoptosis and cell cycle phase distribution.

\section{EXPERIMENTAL}

\section{Chemicals and reagents}

Scopoletin was purchased from Sigma Chemical Company (St Louis, MO, USA).Growth medium RPMI-1640 (Hangzhou Sijiqing Biological Products Co, Ltd, China), Minimum Essential Medium (MEM) (Invitrogen Corp, Carlsbad, CA, USA), Fetal Calf Serum (Gibco Corp, Carlsbad, CA, USA), trypsin, penicillin, MTT, streptomycin, DMSO and phosphate buffer saline (PBS) (Sigma) were used in this study. MTT kit was obtained from Roche (USA). Annexin V-FITCPropidium lodide Apoptosis Detection Kit was purchased from Sigma (USA). All other chemicals and solvents used were of the highest purity grade. Cell culture plastic ware was purchased from BD Falcon (USA).

\section{Cell line}

Human prostate carcinoma (LNCaP) cells were procured from the Shanghai Institute of Cell Resource Center of Life Science (Shanghai, China). The cells were grown in a humidified $5 \%$ $\mathrm{CO}_{2}$ atmosphere at $37{ }^{\circ} \mathrm{C}$ in an incubator, and cultured in RPMI-1640 medium supplemented with $10 \%$ heat-inactivated newborn calf serum, $100 \mathrm{IU} / \mathrm{mL}$ penicillin and $100 \mu \mathrm{g} / \mathrm{mL}$ streptomycin.

\section{Cell viability assay}

The in vitro cytotoxic effect of scopoletin toward human prostate cancer cells (LNCaP) was determined using 3-(4, 5-dimethylthiazol-2-yl)-2, 5-diphenyltetrazolium bromide (MTT) assay. Cells $\left(5 \times 10^{3}\right.$ cells per well) were seeded onto a 96-well plate for $24 \mathrm{~h}$, treated with various concentrations $(20,40,60,80$ and $100 \mu \mathrm{M})$ of Scopoletin, and incubated for an additional 2 days at $37{ }^{\circ} \mathrm{C}$. Thereafter, $10 \mu \mathrm{L}$ of MTT at a concentration of $5 \mathrm{mg} / \mathrm{mL}$ was added to each well, and cells were incubated for an additional 4-6 h. The supernatant was aspirated, and 100 $\mu \mathrm{L}$ of DMSO was added to the wells to dissolve any precipitate present. The absorbance was measured in an ELISA reader (Thermo Molecular Devices Co, Union City, USA) at $570 \mathrm{~nm}$.

Cell inhibition ratio (C) was calculated as in Eq 1.

$C(\%)=\{(\mathrm{Ac} \mathrm{At}) / \mathrm{Ac}\} 100$

Cytotoxicity was expressed as the concentration of scopoletin inhibiting cell growth by $50 \%\left(\mathrm{IC}_{50}\right)$.

\section{Cell cycle analysis by flow cytometry}

LNCaP cells $\left(1 \times 10^{6}\right)$ were seeded in 60-mm dishes and subjected to various concentrations $(0,40,80,100 \mu \mathrm{M})$ of scopoletin for $48 \mathrm{~h}$. Floating and adherent cells were trypsinized and washed three times with PBS. Cells were incubated in $70 \%$ ethanol at $-20{ }^{\circ} \mathrm{C}$ overnight, treated with $20 \mu \mathrm{g} / \mathrm{mL}$ RNase $A$, and stained with $5.0 \mu \mathrm{g} / \mathrm{mL}$ of propidium iodide. Finally the stained cells were analyzed and studied by Flow cytometry at wavelength of $488 \mathrm{~nm}$ (FACS Calibur instrument, BD Biosciences, San Jose, CA, USA) equipped with Cell Quest 3.3 software.

\section{Apoptosis detection using Hoechst 33258 staining}

LNCaP cells were fixed with $4 \%$ formaldehyde in phosphate buffered saline (PBS) for $30 \mathrm{~min}$ before staining with $10 \mu \mathrm{g} / \mathrm{mL}$ of Hoechst 33258 at $37{ }^{\circ} \mathrm{C}$ for $20 \mathrm{~min}$. The cells were treated with different concentrations $(0,40,80,100 \mu \mathrm{M})$ of scopoletin for $48 \mathrm{~h}$. They were then washed once with PBS, and observed under a fluorescence microscope (Nikon). A minimum of 600 cells was counted, and each experiment was performed in triplicate.

Detection of early and late apoptosis, and necrosis by annexin $\mathbf{V}$ binding assay

Apoptosis was demonstrated by annexin $\mathrm{V}$ binding assay using flow cytometry. Briefly, 
LNCaP cells were treated with different concentrations $(0,40,80$ and $100 \mu \mathrm{M})$ of scopoletin for $48 \mathrm{~h}$. Subsequently, treated and untreated cells were harvested by trypsinization. Harvested cells were then incubated in annexin V-FITC $(100 \mathrm{ng} / \mathrm{mL})$ and propidium iodide (40 $\mu \mathrm{g} / \mathrm{mL}$ ), at room temperature for $30 \mathrm{~min}$ in dark, and analysed using a FACS Calibur flow cytometer (BD Bioscience).

\section{Western blot analysis}

To assess the dose-dependent effect of scopoletin, LNCaP cells were treated for $48 \mathrm{~h}$ with various concentrations of scopoletin, (20, 40,60 and $80 \mu \mathrm{M}$ to determine the expression levels of cyclin D1 and cyclin B1). Cellular proteins were extracted using a cell lysis buffer containing $75 \mathrm{mM}$ Tris- $\mathrm{HCl}$ ( $\mathrm{pH} 7.6), 125 \mathrm{mM}$ $\mathrm{NaCl}, 0.1 \%$ sodium dodecyl sulfate (SDS), $1 \%$ NP-40, and 1X proteinase inhibitor cocktail (Roche Applied Science, Indianapolis, IN) [11]. Twenty five micrograms of protein was fractionated by electrophoresis through a $20 \%$ SDS polyacrylamide gel, and the proteins were transferred onto a nitrocellulose membrane. The membrane was further incubated with a secondary anti-rabbit antibody conjugated with horseradish peroxidase (Amersham, Arlington Heights, IL), and the specific protein was detected using a chemiluminescent method (Amersham) followed by autoradiography according to manufacturer's instructions. This procedure was repeated for the detection of cyclin D1 and cyclin B1 proteins, using polyclonal rabbit IgG antibodies at a 1:200 dilution (Santa Cruz Biotechnology, Santa Cruz, CA).

\section{Statistical analysis}

All statistical analyses were carried out with SPSS $\AA$ software (version 19.0) based on oneway analysis of variance (ANOVA) and Tukey test. Data are expressed as mean \pm SEM, and $p$ $<0.05$ was considered significant.

\section{RESULTS}

\section{Anti-proliferative activity of scopoletin}

The effect of scopoletin treatment on the prostate cancer cell viability is shown in Fig 1. Scopoletin exhibited potent and dose-dependent cytotoxic activity against these cancer cells. The $\mathrm{IC}_{50}$ value of the extract was calculated to be $65.1 \mu \mathrm{M}$. As shown in Figure 1, $100 \mu \mathrm{g} / \mathrm{mL}$ extract exhibited a very strong anti-proliferative effect at which approximately only $7.91 \%$ of the cells were found live and $92 \%$ dead.

\section{Effect of scopoletin on cell cycle phase distribution in human prostate cancer cells (LNCaP)}

The results showed that treatment with different concentrations of scopoletin for $48 \mathrm{~h}$ led to an increase in the population of cells in the subG0/G1 phase (apoptotic population) $(p<0.01)$ (Fig 2).

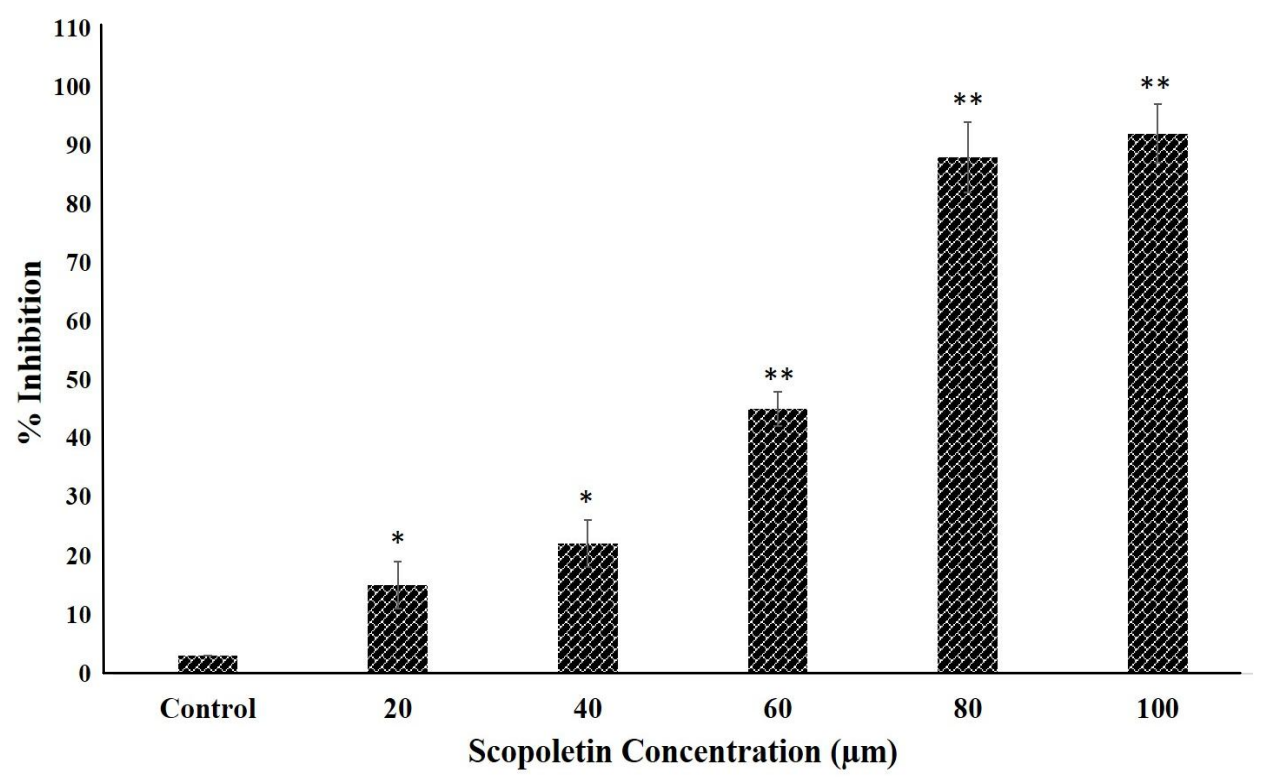

Figure 1: Cancer growth inhibition shown by scopoletin against prostate cancer cells in vitro at various concentrations; ${ }^{*} p<0.05$ vs. control group; ${ }^{* *} p<0.01$ vs. control group 
The decline in the $S$ phase population was attended by considerably increased G2/M phase population $(p<0.01)$ after $48 \mathrm{~h}$ treatment compared to the control, suggesting cell cycle arrest at the G2/M phase in scopoletin-treated cells. At 80 and $100 \mu \mathrm{M}$ scopoletin, the cells had no increment in the $G 2 / M$ population but increased in the sub-G1 population compared to the control, suggesting that cells were arrested at the G2/M phase followed by significant apoptotic cell death over time.

\section{Hoechst 33258 staining to detect apoptosis in LNCaP cancer cells}

Scopoletin treatment resulted in the appearance of cell shrinkage along with membrane blebbing which are characteristic features of cell apoptosis (Fig 3).

Effect of scopoletin on early and late apoptosis, and necrosis in LNCaP cells

The results of the flow cytometry study with Annexin V/FITC and PI showed that within $48 \mathrm{~h}$ of incubation, approximately $15.45,32.6$ and $21.71 \%$ of the cells underwent early apoptosis after treatment with 40,80 and $100 \mu \mathrm{M}$ of scopoletin respectively. Similarly, 6.0, 15.71 and $54.1 \%$ of the cells underwent late apoptosis after treatment with 40,80 and $100 \mu \mathrm{M}$ of scopoletin, respectively. Necrotic cell death also increased from $0.21 \%$ (control, untreated cells) to $2.1,6.31$ and $9.11 \%$ after treatment with 40,80 and 100 $\mu \mathrm{M}$ of scopoletin, respectively as shown in Fig 4.

\section{Effect of scopoletin on cell cycle-regulating molecules (cyclin D1 and Cyclin B1)}

Cyclin D expression diminished in a concentration-dependent manner when LNCaP cells were treated with different concentrations $(20,40,60$ and $80 \mu \mathrm{M})$ of scopoletin (Fig. 5). Thus scopoletin inhibits the expression of cyclin D1 in human prostate cancer cells resulting in G2/M cell cycle arrest. The level of expression of cyclin B1 did not change much on scopoletin treatment.
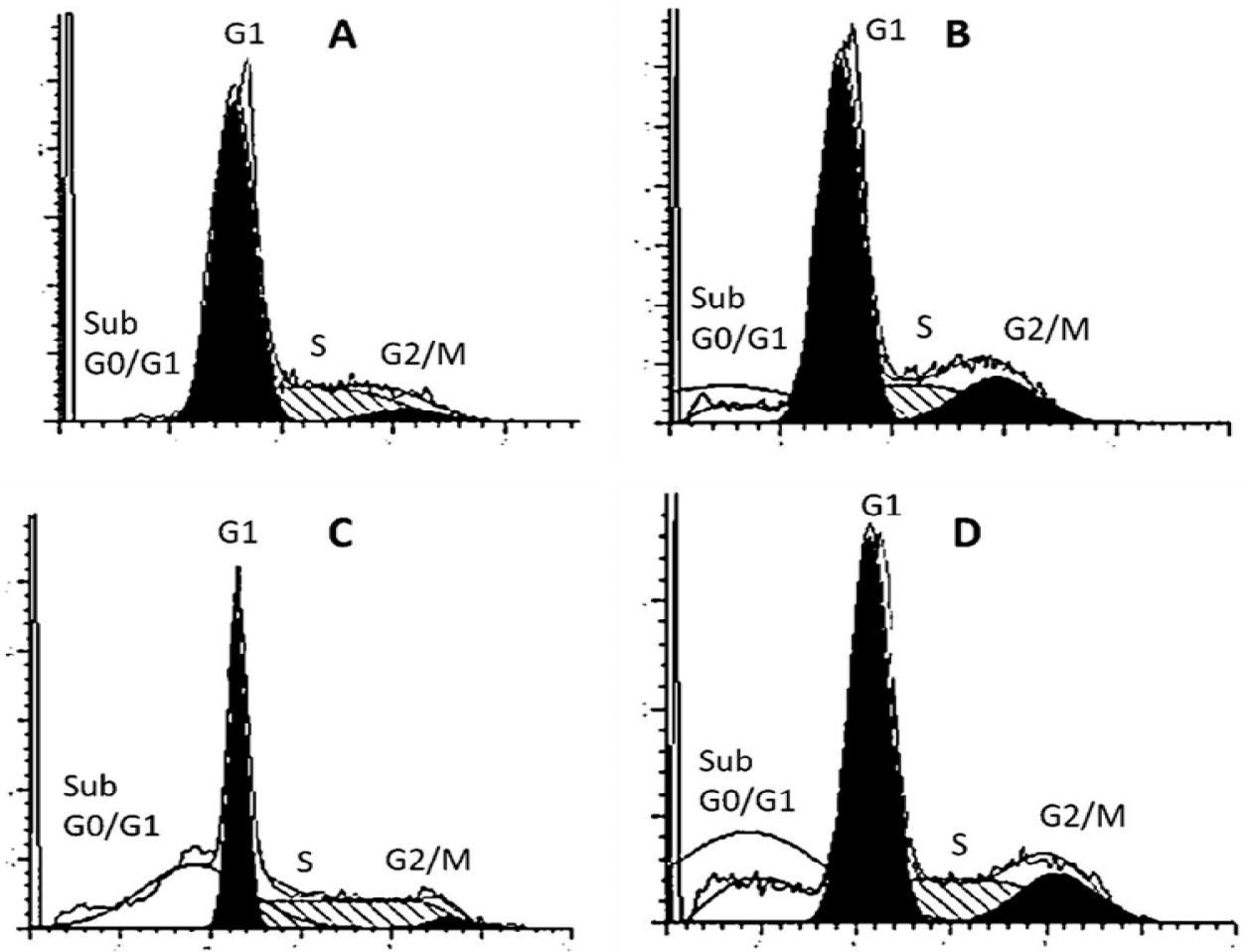

Figure 2: Effect of scopoletin on cell cycle phase distribution in LNCaP cells. Scopoletin induces cell cycle arrest at G2/M phase in human prostate cancer (LNCaP) cells and increased G0/G1 (apoptotic) cell population. The cell cycle distribution was determined by propidium iodide staining and flow cytometry. LNCaP cells were treated with scopoletin at different concentrations $(40,80$ and $100 \mu \mathrm{M}, \mathrm{B}, \mathrm{C}$ and D respectively). Untreated cells (A) were included as controls. The DNA histogram shows the distribution and the percentage of cells in phases of the cell cycle. Results are the mean \pm SD of 3 independent experiments; $p<0.01$ compared to the control. Each DNA histogram represents one of the three independent experiments 

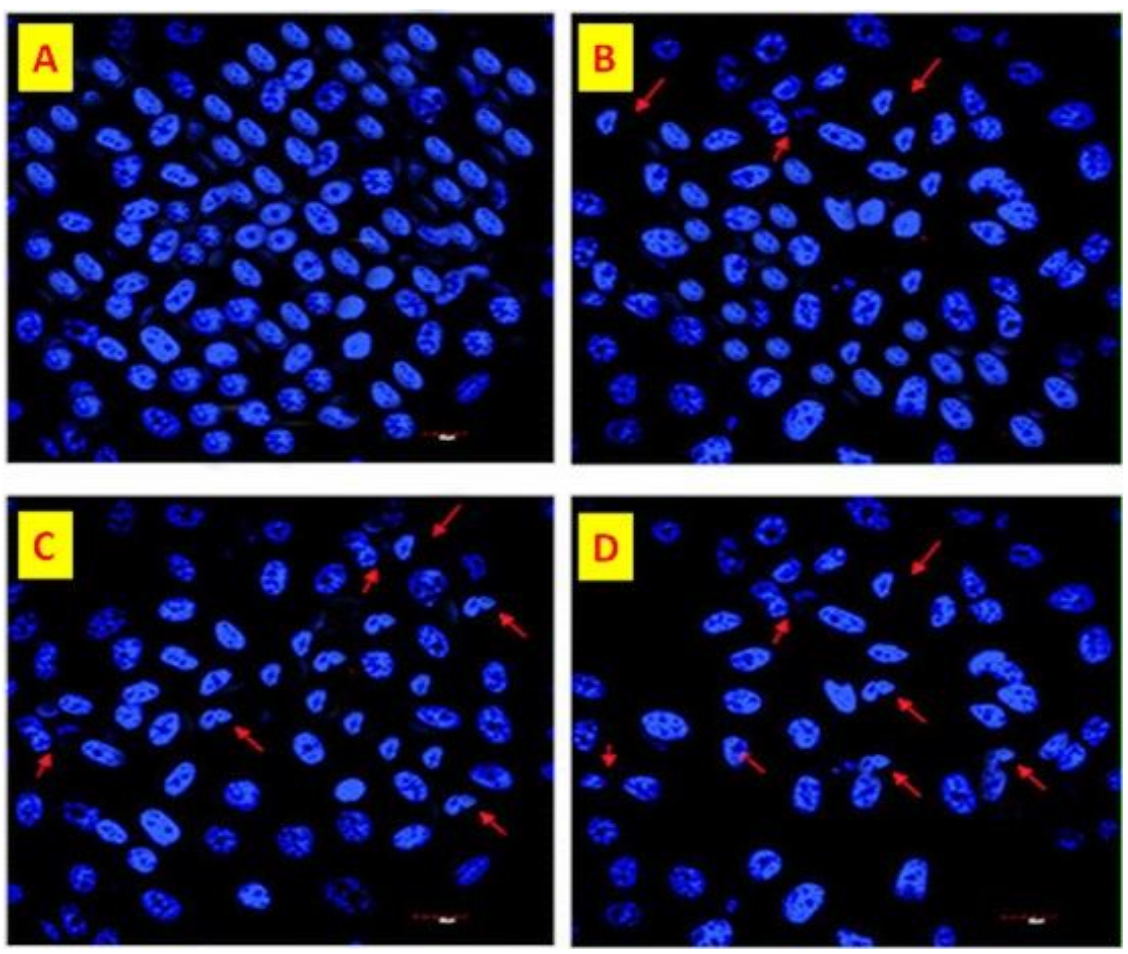

Figure 3: Induction of apoptotic nuclear morphology of LNCaP cells treated with scopoletin. Nuclear morphology was analyzed by fluorescence microscopy upon staining with Hoechst 33258. LNCaP cells were cultured in the absence (A) or presence of $40 \mu \mathrm{M}(\mathrm{B}), 80 \mu \mathrm{M}(\mathrm{C})$ and $100 \mu \mathrm{M}(\mathrm{D})$ of scopoletin for $48 \mathrm{~h}$, stained with Hoechst 33258 and analysed as described in Experimental section. Arrows indicate the nuclear chromatin condensation foci

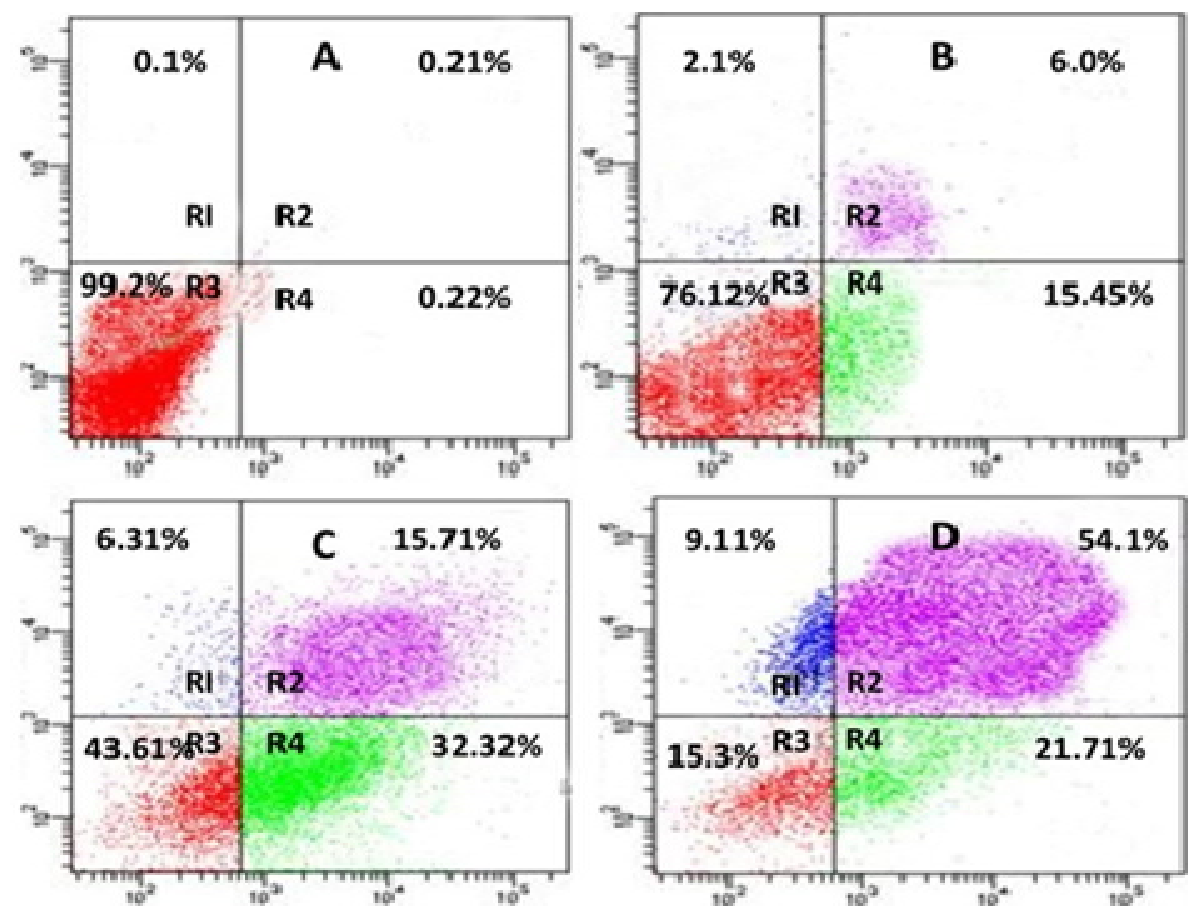

Figure 4: Induction of apoptosis by scopoletin and confirmation by Annexin V-FITC/PI dual staining. LNCaP cells were treated with $40 \mu \mathrm{M}(\mathrm{B}), 80 \mu \mathrm{M}(\mathrm{C})$ and $100 \mu \mathrm{M}(\mathrm{D})$ of scopoletin for $48 \mathrm{~h}$ and analysed using FACS Calibur flow cytometer as described in Experimental section. A, represents experiment control of untreated cells alone. Normal healthy, early apoptotic, late apoptotic and dead/necrotic cell populations are shown as percentage of total cells in the quadrants R3, R4, R2 and R1, respectively 


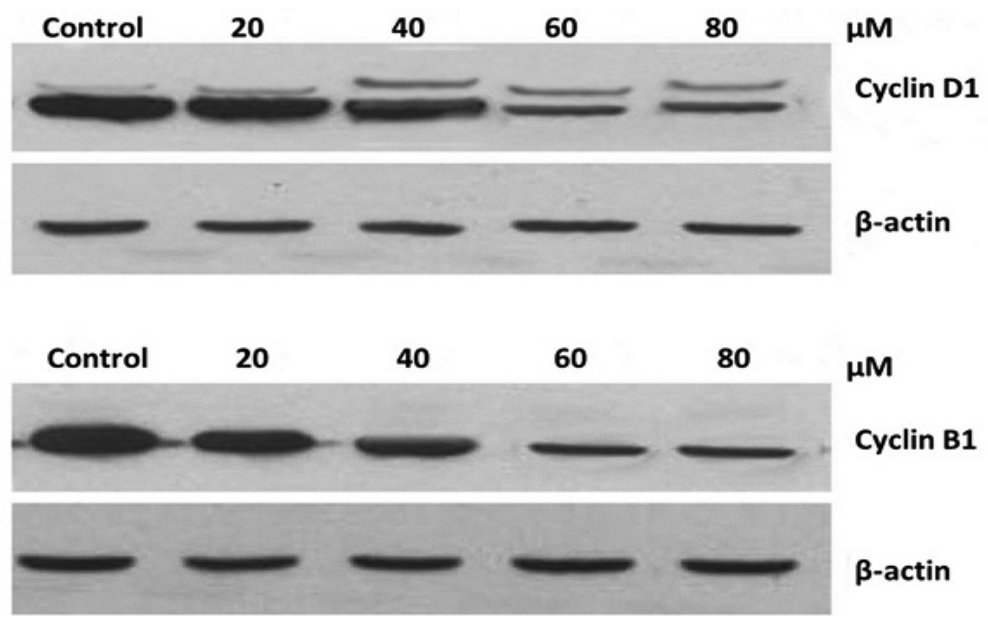

Figure 5: Effect of Scopoletin on cyclin D1 and cyclin B1 protein expression. LNCaP and PC-3 cells were treated with various indicated concentrations of scopoletin for $48 \mathrm{~h}$, and the expression levels of cyclin D1 and cyclin B1 were determined by Western blot. $\beta$-Actin was used as an internal control $(n=3)$

\section{DISCUSSION}

Natural products have always been the preferred option of all as it plays an immense role in the healthcare and various traditional medicine systems of the world.

According to an estimate by World Health Organization, $80 \%$ of the world's population relies mainly on traditional medicines for their primary health care [15]. Coumarins are a class of natural compounds widely distributed in plants having low toxicity in the humans $[16,17]$. They possess several biological activities such as antibacterial [18], anti-platelet [19] vasodilatatory [20], anti-asthmatic [21] and anti-mutagenic [22] anti-tumourigenic activity [23-26]. Coumarins and their derivative compounds have been used in clinical treatment, alone or in combination therapy, of various malignant cancers, such as renal, lung and kidney carcinoma and malignant melanoma [27]. Scopoletin (6-methoxy-7hydroxycomarin) is a phenolic coumarin and an important member of the group of phytoalexins isolated from many plants.

Studies have shown that scopoletin and its synthetic derivatives exhibit anticancer activity against mammary (MCF-7 and MDA-MB 231) and colon (HT-29) carcinoma cells [28]. In this study we found that scopoletin reduced the expression levels of cyclin D1 in androgendependent manner and caused cell cycle arrest at $\mathrm{G} 2 / \mathrm{M}$ phase and induced early and late apoptosis in human prostate cancer cells $(\mathrm{LNCaP})$. As it has been found that the elevated levels of cyclin D1 promote prostate cancer development by reducing its dependence on androgen stimulation [29]. The ability of scopoletin to affect cell cycle regulating molecules is an important finding making it an essential natural product for the development of chemotherapeutic agents against the prostate cancers.

\section{CONCLUSION}

The findings of this study indicate that scopoletin exhibits potent anticancer activity by inducing apoptosis, cell cycle arrest and down regulating the expression of cyclin D1 levels in human prostate cancer (LNCaP) cells, thus making it an important natural product for the development of chemotherapeutic agents against prostate cancers and paving a way to elucidate further the mechanism of its action in order to make it more efficient against human prostate cancers.

\section{REFERENCES}

1. Hsing AW, Devesa SS, Jin F, Gao YT. Risng Incidence of Prostae Cancer in Shanghai, China. Cancer Epidemiol Biomarkers Prev 1998; 7(1): 83-84.

2. Jemal A, Siegel R, Ward E, Murray $T, X u J$, Smigal C, Thun MJ. Cancer statistics, 2006. CA Cancer J Clin 2006; 56(2):106-130.

3. Chu KC, Tarone RE, Freeman HP. Trends in prostate cancer mortality among black men and white men in the United States. Cancer 2003; 97(6): 1507-1516.

4. Eton D, Lepore S. Prostate cancer and health-related quality of life: a review of the literature. Psychooncology 2002; 11(4): 307-326.

5. Eisenberg DM, Davis RB, Ettner SL, Appel S, Wilkey S, Van Rompay M, Kessler RC. Trends in alternative medicine use in the United States, 1990-1997: results of a follow-up national survey. JAMA 1998; 280(18): 1569-1575. 
6. Zimmerman RA, Thompson IM Jr. Prevalence of complementary medicine in urologic practice: a review of recent studies with emphasis on use among prostatecancer patients. Urol Clin North Am 2002; 29(1): 1-9.

7. Tal B, Robeson DJ. The induction, by fungal inoculation of ayapin and scopoletin biosynthesis in Helianthus annuus. Phytochemistry 1986; 25: 77-79.

8. Hiroki $T$, Sueo $H$, Sansei $N$, David $G$, Roux, John P. Coumarins from Olea africana and Olea capensis. Phytochemistry 1984; 23(3): 699-700.

9. Mizuo M, Hiroyuki K, Munekazu L, Toshiyuki T, Kiyoto G. Coumarin Derivatives In Coptis trifolza. Phytochemistry 1992; 31(2): 717-719.

10. Soad AL, Bayoumi MG, Blagbrough IS, Beeching JR. Biosynthesis of scopoletin and scopolin in cassava roots during post-harvest physiological deterioration: The E-Z-isomerisation stage. Phytochemistry 2008; 69(17): 2928-2936.

11. Pan R, Gao XH, Li Y, Xia YF, Dai Y. Anti-arthritic effect of scopoletin, a coumarin compound occurring in Erycibe obtusifolia Benth stems, is associated with decreased angiogenesis in synovium. Fundam Clin Pharmacol 2010; 24(4): 477-90.

12. Pan R, Gao XH, Lu D, Xu X, Xia Y, Dai Y. Prevention of FGF-2-induced angiogenesis by scopoletin, a coumarin compound isolated from Erycibe obtusifolia Benth, and its mechanism of action. Int $J$ Immunopharmacol 2011; 11(12):2007-16.

13. Cheng AS, Cheng YH, Chang TL. Scopoletin attenuates allergy by inhibiting Th2 cytokines production in EL-4 $T$ cells. Food Funct 2012; 3(8):886-90.

14. Pan R, Dai Y, Gao XH, Lu D, Xia YF. Inhibition of vascular endothelial growth factor-induced angiogenesis by scopoletin through interrupting the autophosphorylation of VEGF receptor 2 and its downstream signaling pathways. Vascular Pharmacol 2011; 54(1-2):18-28.

15. Farnsworth NR, Akerele $O$, Bingel AS, Soejarto $D D$, Guo Z. Medicinal plants in therapy. Bull World Health Organ 1985; 63(6): 965-972.

16. Egan D, O'Kennedy R, Moran E, Cox D, Prosser E, Thornes RD. The pharmacology, metabolism, analysis, andapplications of coumarin and coumarinrelated compounds. Drug Metab Rev 1990; 22(5): 503-529,

17. Cox $D$, O'Kennedy R, Thornes RD. The rarity of livertoxicity in patients treated with coumarin (1,2benzopyrone). Hum Exp Toxicol 1989; 8(6): 501506 ,

18. Laurin $P$, Klich $M$, Dupis-Hamelin $C$, Mauvais $P$, Lassaigne $P$, Bonnefory A, Musicki B. Synthesis and in vitro evaluationof novel highly potent coumarin inhibitors of gyrase B. Bioorg Med Chem Lett 1999; 9(14): 2079-2084.

19. Roma G, Braccio MD, Carrieri A, Grossi G, Leoncini G,Signorello MG, Carotti A. Coumarin, chromone, and 4(3H)-pyrimidinone novel bicyclic and tricyclic derivatives as antiplateletagents: synthesis, biological evaluation, and comparative molecular field analysis. Bioorg Med Chem 2003; 11(1):123-138.

20. Campos-Toimil M, Orallo F, Santana L, Uriarte E. Synthesis and vasorelaxant activity of new coumarin and furocoumarin derivatives. Bioorg Med Chem Lett 2002;12(5): 783-786.

21. Fang $Y, L i Z$, Watanabe $Y$. Pharmacokinetics of a novelanti-asthmatic, scoparone, in the rabbit serum assessed by asimple HPLC method. J Ethnopharmacol 2003; 86(1): 127-130.

22. Pillai SP, Menon SR, Mitscher LA, Pillai CA, Shankel DA. Umbelliferone analogues and their potential to inhibit Benzo(a)pyrene and hydrogen peroxide induced mutations. J Nat Prod 1999; 62(10): 1358-1362.

23. Maucher A, Kager M, von Angerer E. Evaluation of the antitumour activity of coumarin in prostate cancer models. J Cancer Res Clin Oncol 1993; 119(3): 150154.

24. Sharma S, Stutzman D, Kellof JG, Steele VE. Screening of potential chemopreventive agents using biochemical markers of carcinogenesis. Cancer Res 1994; 54(22): 5848-5855.

25. Egan D, James $P$, Cooke $D$, O'Kennedy R. Studies on the cytostatic and cytotoxic effects and mode of action of 8-nitro-7-hydroxycoumarin. Cancer Lett 1997;118(2): 201-211.

26. Hayes JD, Pulford DJ, Ellis EM, McLeod R, James RFL, Seidegard J, Mosialou E, Jernstrom B, Neal GE. Regulation of rat glutathione S-transferase A5 by cancer chemo-preventative agents: mechanisms of inducible resistance to aflatoxin B1. Chemicobiol Interact 1998; 111-112: 51-67.

27. Lake BG: Coumarin metabolism, toxicity and carcinogenicity: relevance for human risk assessment. Food Chem Toxicol 1999; 37(4):423453.

28. Liu W, Hua J, Zhou J, Zhang H, Zhu H, Cheng Y, Gust R. Synthesis and in vitro antitumor activity of novel scopoletin derivatives. Bioorg Med Chem Lett 2012; 22(15):5008-12.

29. Chen Y, Martinez L, LaCava M, Coghlan L, Conti C. Increased cell growth and tumorigenicity in human prostate LNCaP cells by over expression to cyclin D1. Oncogene 1998; 16(15): 1913-1920. 